\title{
Which form of agreement works for community- based management? A case study from southwestern Madagascar
}

\author{
Katinka Thielsen'
}

\section{ABSTRACT}

Aware that humans and nature are inseparably linked many organisations in Madagascar support the community-based natural resource management approach to promote the international policy of biodiversity conservation and protection. In this context, community associations have been introduced to transfer management and use rights for natural resources to the local population. However, the fast, donor-driven top-down procedure of establishing new rules contradicts the local rhythm and handling of rules. Against this background, this paper focuses on the ethnic group Tanalana and explores key actors and locally initiated rules and agreements, analyses their level of effectiveness and discusses their possible application for community-based natural resource management in the buffer zone of Tsimanampesotse National Park in southwestern Madagascar. The paper looks at an example of rule negotiation outside the community-based management context concerning the use of a key resource in raising livestock. The example demonstrates that, on the one hand, the overlapping memberships in different social and kinship groups, and on the other hand, different individual economic interests can hinder successful collective action for natural resource management. Moreover, this example shows that already existing or newly introduced rules can be further called into question and are variously interpreted depending on the context. The degree of sanctions depends on several factors: (i) frequency of transgression, (ii) amount of affected persons, (iii) social relationships between the concerned parties and (iiii) social and communicative behaviour of the transgressor (in the past and present). This study finds that rules serve as rough guidelines, as a basis for discussion in cases of transgression, but do not function as fixed prescriptions. The data for this study was collected through semi-structured interviews and participative observation in six fokontany (village and related hamlets) to the east and west of Tsimanampesotse National Park.

\author{
Correspondence: \\ Katinka Thielsen \\ Ernst Moritz Arndt-Universität Greifswald, Institut of Geography \\ 17489 Greifswald, Germany \\ Email: katinka.thielsen@staff.uni-marburg.de
}

\section{RÉSUMÉ}

Dans le contexte de la protection et de la conservation de la biodiversité, de nombreuses organisations de développement appuient la création d'organismes et la formulation de réglementations en vue d'une gestion durable des ressources naturelles autour des aires protégées de Madagascar. Dans la zone tampon du Parc National Tsimanampesotse, des transferts des droits d'usage et de gestion des ressources naturelles d'un territoire précis à la population locale, suivant l'approche de community-based management, ont été réalisés. Dans la mesure où la population rurale dépend étroitement des ressources naturelles, la nécessité de son intégration participative dans le processus de la protection est évidente. L'objectif premier d'instaurer de nouvelles règles sur les structures locales préexistantes était rarement réalisable à cause de la rapidité de l'élaboration des contrats de transfert de gestion. La présente recherche se concentre sur le groupe ethnique Tanalana, en tant que plus grand groupe de cette région et principal utilisateur des ressources naturelles du territoire du Parc National Tsimanampesotse, dans la région Atsimo Andrefana dans le sud-ouest de Madagascar. Les acteurs clés et la négociation des règles locales sont ici exposés pour analyser leur domaine d'action et discuter leur applicabilité dans le contexte du community-based natural resource management. L'exemple d'un processus de négociation pour la gestion d'une ressource clé pour l'élevage hors du contexte de community-based management montre les différents facteurs qui compliquent une action collective à succès pour la gestion des ressources naturelles : d'un côté une personne est simultanément membre des différent groupes sociaux et parentaux qui déterminent des droits et obligations pour l'utilisation des ressources et de l'autre côté les individus ont des intérêts économiques différents qui, selon leur position sociale, influencent les décisions collectives. En outre, cet exemple montre que les règles existantes ou nouvellement mises en place peuvent être remises en question et interprétées différemment selon le contexte. L'étude de cas a été menée de manière qualitative dans six fokon- 


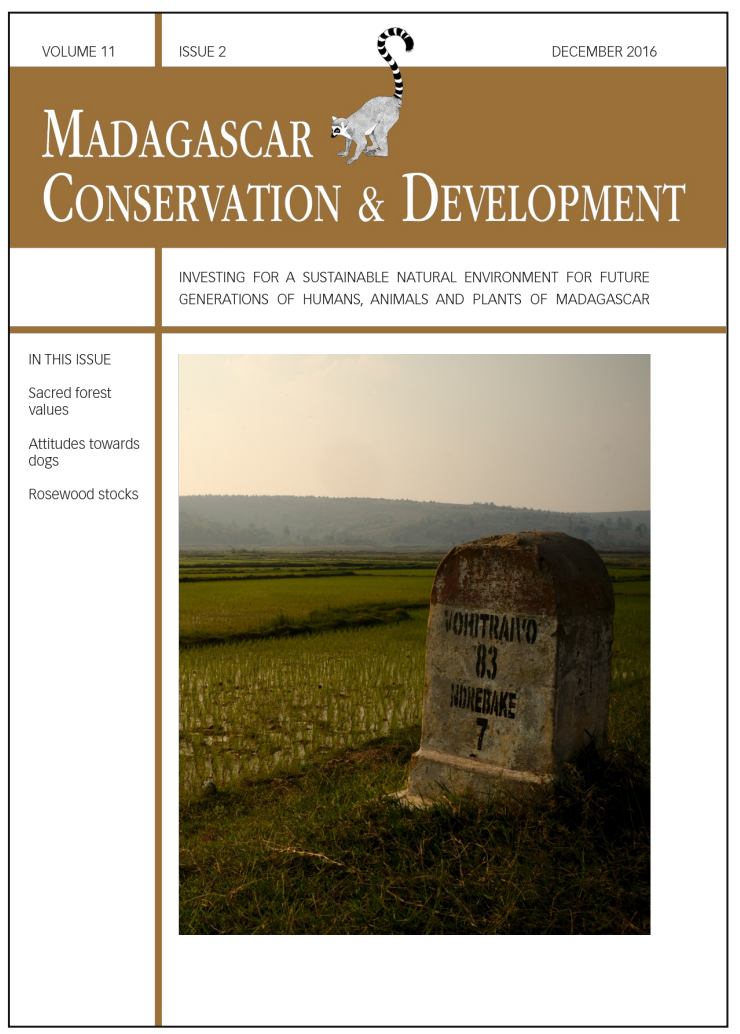

Madagascar Conservation \& Development is the journal of Indian Ocean e-Ink. It is produced under the responsibility of this institution. The views expressed in contributions to MCD are solely those of the authors and not those of the journal editors or the publisher.

All the Issues and articles are freely available at http://www.journalmcd.com

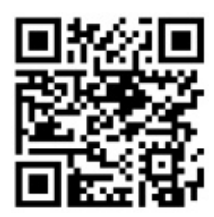

Contact Journal MCD

info@journalmcd.net for general inquiries regarding MCD funding@journalmcd.net to support the journal

Madagascar Conservation \& Development Institute and Museum of Anthropology

University of Zurich

Winterthurerstrasse 190

$\mathrm{CH}-8057$ Zurich

Switzerland

Indian Ocean e-Ink

Promoting African Publishing and Education

www.ioeink.com

Missouri Botanical Garden (MBG)

Madagascar Research and Conservation Program BP 3391

Antananarivo, 101, Madagascar 
tany à l'ouest, vers le littoral, et à l'est sur le plateau du Parc National dans la commune de Beheloke, via des interviews semistructurées des divers acteurs individuels et collectifs. Les membres de cette société agro-pastorale, se déployant des deux côtés du Parc, sont liés à travers une même origine, le mouvement bidirectionnel de la transhumance et le commerce. Pour mieux comprendre l'interaction sociale et le processus de négociation des intérêts dans la gestion des ressources, nous avons également mené une observation participative à plusieurs réunions et activités quotidiennes.

\section{INTRODUCTION}

Madagascar's status as a 'biodiversity hotspot' (Myers et al. 2000) attracted the World Bank and international conservation groups in 1988 to technically and financially support the Malagasy Government for the elaboration of the National Environmental Action Plan (NEAP), carried out in three phases from 1990-2008 (Hanson 2012). The plan aims to find solutions for Madagascar's environmental problems such as deforestation, loss of biodiversity, erosion and soil degradation (Mercier 2006). The main objectives of the first phase (1990-1997) were the establishment of an institutional infrastructure for conservation activities in already existing and newly established protected areas, and the promotion of Integrated Conservation Development Projects (ICDP), which aimed to provide alternative income possibilities to resource use for local people living in the peripheral zones of protected areas (Marcus and Kull 1999, Raik 2007, Hanson 2012). The donor-driven ICDP approach did not meet local needs because of its standardized and inflexible character. It failed to improve the economic conditions for the local population and consequently did not manage to exclude humans from resource use in protected areas (Marcus and Kull 1999, Raik 2007, Pollini 2011, Hanson 2012, Waeber et al. 2016).

During the second phase of the NEAP (1997-2002) the focus was on the implementation of a new, participatory bottom-up management approach, community-based management (CBM). Two laws were enacted in Madagascar aimed at decentralising government control over natural resources, both of which enabled a contractual transfer of management rights of natural resources to the local population: the GELOSE-law (Gestion Locale Sécurisée) of 1996 applies to forest, pasture, wildlife and water; the GCF-law (Gestion Contractuelle des Forêts) of 2001 specifies the management of forest resources and facilitates the administrative procedure (Antona et al. 2004). With strong support from non-governmental organisations (NGOS), about 1200 voluntary user associations- named COBAs (Communauté de base)-were founded in the 22 regions of Madagascar (Bertrand et al. 2014) to develop their own rules and sanctions for natural resource use and to control compliance in the transferred areas (Kull 2002). The extendable three-year COBA contracts determine the time period and amount of resource use to be regulated; for resource users, a fee-based authorisation is required from the association's executive board.

Several authors have observed the CBM movement in various regions of Madagascar and have identified many problems, questioning the compatibility with local social structures (BlancPamard and Fauroux 2004, Goedefroit 2006, Fritz-Vietta et al. 2009, Bérard 2011, Pollini 2011, Pollini et al. 2014). Many researchers criticise development agencies' "race of contracts" (Bérard 2011), which very often causes a 'one-size-fits-all' approach resulting in a lack of participation by local people (Pollini et al. 2014). Instead of supporting entire local communities in the development of their own rules (bottom up), 'stereotyped rules' are introduced in artificially created entities that represent only one part of the whole user community (top down) (Blanc-Pamard and Fauroux 2004, Bérard 2011, Pollini 2011). For local populations, access to natural resources is determined by historically grown relationships; the dynamic social rules and norms structure the communication and interaction between individuals and groups (Fritz-Vietta et al. 2011). Each ethnic group has to be studied in its own context to understand all the dynamics in detail. The present study hence focuses on one ethnic group, the Tanalana, exploring their rules and procedures in decision making to discuss their applicability in the CBM context.

Many authors have investigated local rules in the context of natural resource management at different places in Madagascar (Horning 2000, Kull 2002, Horning 2003a, b, 2004, Muttenzer 2006, 2010, Bérard 2011 but this paper is the first to focus on the ethnic group Tanalana living in southwest Madagascar. Horning (2003a, b) and Muttenzer $(2006,2010)$ point out that it is important to consider customary rules as syncretic constructs of different historical moments, not as timeless and fixed entities. Bérard (2009 and 2011) confirms this statement by demonstrating that customary rules are adaptable to the situation and are in a constant state of change. In a context of legal pluralism, researchers regularly wonder about the (in)stability of local and formal rules and try to identify the factors of (non-)compliance (Horning 2000, 2003a, b). Horning (2000), Kull (2002) and Gardner et al. (2008) conclude that local rules under certain circumstances can be more effective and sustainable for natural resource management than formal rules introduced by the state or those supported by conservation agencies. This study contributes to this discussion by demonstrating the procedures of establishing and handling rules and pacts among the Tanalana in southwestern Madagascar and testing their applicability as a basis for the CBM approach.

After presenting the study area and the methodology, this paper describes Tanalana society. Key actors and procedures for decision making are outlined in order to understand the negotiation of rules for resource management, especially for a fodder plant. Finally, the importance of these findings is discussed in the context of the CBM approach.

\section{STUDY AREA}

Tsimanampesotse National Park (literally "sea/lake without dolphins") was originally founded as the Réserve Naturelle Intégrale in 1927 with 17,520 ha in southwestern Madagascar. This area was expanded to 43,200 ha by 1966 and became a National Park in 2002. The third phase of the NEAP, started in 2003, was inspired by the 'Durban Vision' of president Ravalomanana, who decided in the course of the Fifth World Parks Congress in South Africa in to expand Madagascar's protected area (marine and terrestrial) from 1.7 (3\%) to 6 million ha (10\% of the total surface) by 2012 (Freudenberger 2010). In this context, Tsimanampesotse National Park's area was quintupled between 2005 and 2007 from 43,200 to 203,744 ha. The whole area of the park currently extends from the Onilahy River in the north to the Menarandra River in the south and affects six rural communes (Beheloke, Itampolo, Androka, Ampanihy, Ejeda and Beahitse) in two districts (Tuléar ॥ and Ampanihy West) in the region Atsimo Andrefana. The Park is part of the geographic region the Mahafaly Plateau, which is com- 
posed of a coastal zone along the Mozambique Channel in the west and a limestone plateau in the east. The study area encloses six fokontany (smallest deconcentrated administrative unit, composed of one or more villages and their related hamlets) in the rural commune Beheloke (District Tuléar II) in the north of Tsimanampesotse National Park (Figure 1).

The buffer zone of the whole park consists of 31 communitybased management areas, each managed by a COBA (Communautés de Bases) (cf. Waeber et al. 2015) (Figure 1). Four organisations support the establishment of COBA contracts, which are mainly based on GCF law, and accompany the resource management activities in the transferred areas: the NGOs Tany Meva Foundation and World Wide Fund for Nature (WWF), the German federal agency GIZ, and the (semi) state agency Madagascar National Parks (MNP), which is also responsible for the management of the National Park.

While the associations of the buffer zone establish their own rules (dina GELOSE or dina COBA), the management of the National Park is based on the national legislation COAP (Code des Aires protégés) and a supplementary park-specific rule system controlled by MNP. The forest area outside the protected areas is also under the jurisdiction of the State (Supplementary Material). Countrywide, MNP rangers and forest state agents (chef de cantonnement forestier) govern extensive areas, receive low salary and do not have enough equipment to fulfil their tasks in an effective manner (Bertrand et al. 2014, Cullmann 2015). Consequently, access to forest products is 'quasi free' for the local population; yet this is far from a 'free rider' concept as access to land and natural resources is organised by customary rules (Goedefroit 2006).

The ethnic group Tanalana are the main inhabitants of the northern periphery of the National Park. The Tanalana are categorized in the official administrative terminology as 'Mahafaly,' one of eighteen ethnic group identities introduced by the French colonial rulers and adopted thereafter by the Malagasy government, researchers and NGOS (Larson 1996). This designation encompasses all ethnic groups living to the south of the Onilahy River on the Mahafaly Plateau and does not take account of the ethnic heterogeneity in this area (Eggert 1981). Interviewees perceive them-

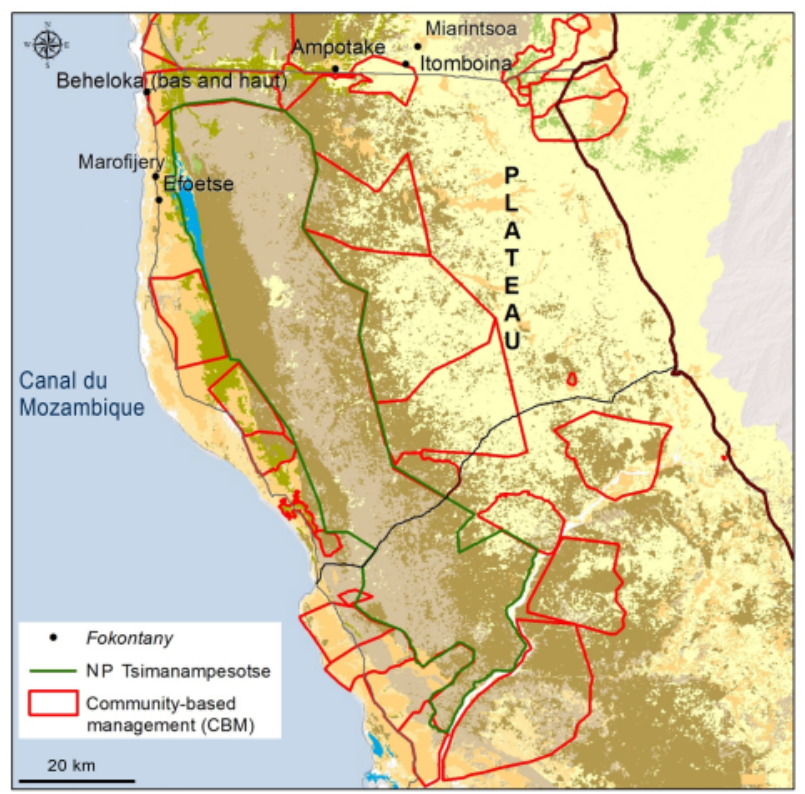

Figure 1. Tsimanampesotse National Park, community-based management areas and study sites fokontany. (Source SuLaMa, LandSat 2006) selves as Tanalana ("inhabitants of the coastal plain"), historically originating from the Androy and Anosy region in southern Madagascar. They distinguish themselves from other Mahafaly groups. At the end of the 15th century, the Tanalana first settled in the littoral of the Mozambique Channel before they went on to populate the limestone plateau in the east, where they found better conditions for agriculture and raising livestock during the dry season (Esoavelomandroso 1989). Currently living on both sides of Tsimanampesotse National Park (Figure 1), members of this agro-pastoral society are closely connected by a common origin (lineage and clan affiliation) and through social interactions such as rituals, transhumance movement in both directions, and commerce. The Tanalana live in a semi-arid area where they mainly practice subsistence agriculture and animal husbandry and are highly dependent on the exploitation of natural resources (e.g., fuel wood, construction material, fodder plants for livestock, medicinal plants).

While the Tanalana are the main users of natural resources in the study area, there are two other user groups living in the vicinity of Tsimanampesotse National Park. The Vezo Sara comprises various groups from the north settled along the shoreline, who mainly practice fishing (for a discussion of Vezo identity see Astuti 1995); the Mahafaly are composed of different groups in the east of the limestone plateau, who like the Tanalana, mainly practice agriculture and animal husbandry. Inter-ethnic marriage and flexible adoption of activities, originally linked to the other ethnic group, connect these groups. For example, two decades ago many of the Tanalana, especially those who are not in contact with livestock, started to also practice fishing (mainly without a pirogue), while vezo also work the land and accumulate small ruminants. Nevertheless, social rules differ amongst the three groups (taboos, performance and manner of rituals). The sense of belonging for the Tanalana is shaped by the agro-pastoralism lifestyle (e.g., Poyer and Kelly 2000), their social rules and the self-allocation to a clan chieftaincy, whose foundation can ideologically be traced to the founding fathers of the Tanalana.

\section{METHODOLOGY}

The data was collected in two phases through diverse qualitative research techniques. First, the SuLaMa (Sustainable Landmanagement in southwestern Madagascar) project team of Malagasy and German researchers conducted an interdisciplinary (agronomy, biology, forestry, ecology, anthropology) exploratory case study. By applying semi-structured interviews and group discussions, the aim was to identify different collective and individual actors on the local and regional levels and to gain insight on social structures and local perspectives of resource use. I use the term 'local' to describe the family, lineage, clan, fokontany and commune level, the last being in a maximum distance of eight hours by feet for all the inhabitants of the commune Beheloke. This first study was conducted in four fokontany east and west of the National Park, in Efoetse (E $043^{\circ} 41^{\prime} 54.8^{\prime \prime}, \mathrm{S} 24^{\circ} 04^{\prime} 42.4^{\prime \prime}$ ), Marofijery (E $043^{\circ} 42^{\prime} \mathrm{O}^{\prime \prime}$,

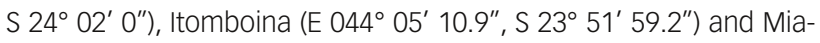
rintsoa ( $\mathrm{E} 044^{\circ} 06^{\prime} 17.7^{\prime \prime}, \mathrm{S} 23^{\circ} 50^{\prime} 14.2^{\prime \prime}$ ), each for the duration of one week in 2011 (SuLaMa 2011). The fokontany were selected applying the following criteria: (i) membership in the rural commune Beheloke (2004: 13,117 inhabitants) (Commune de Beheloke 2005) and (ii) participation in one of the management systems of the National Park (co-management of the Park and/or CBM of the buffer zone). 
For the second phase, an extended case study approach was chosen (sensu Yin 2003) to assess the perspectives of the local individuals and collective actors and to understand their social interactions in the process of interest negotiations concerning natural resource use. In collaboration with two research assistants, in-depth data collection was carried out for six non-consecutive months from 2011-2014 in three fokontany in the littoral, Beheloke Haut (E $043^{\circ} 40^{\prime} 16.5^{\prime \prime}, \mathrm{S} 23^{\circ} 54^{\prime} 33.5^{\prime \prime}$ ), Marofijery and Efoetse, and three fokontany on the plateau, Ampotake (E $043^{\circ} 58^{\prime}$ 36.6", S $23^{\circ} 52^{\prime} 27.8^{\prime \prime}$ ), Itomboina and Miarintsoa. The four fokontany from the first study were chosen and two more were added that were identified as important during the first research phase: Beheloke Haut is the administrative centre of the rural commune and the seat of a clan chief, and Ampotake has the COBA association governing the largest forest area located in the north outside the National Park (Figure 1).

The main research method for gathering information for this study was the semi-structured interview. With the help of Malagasy-French speaking assistants, interviews were conducted with 125 local people, 94 men and 31 women aged 15 to 80 years from different clans and lineages of the Tanalana, who are the main users of natural resources in the study area. These included persons with traditional (lineages elders including chiefs) or administrative (chef de fokontany, mayor and the corresponding deputies and assistants) power, who are relevant for decision making over natural resource use and other members of the society, who practice different natural resource-dependent activities such as agriculture, pastoralism, household, carpentry. Additionally, we interviewed eleven conservation practitioners from NGOS and (inter-)national agencies (Tany Mena, WWF, MNP, GIZ). Relevant actors for interviews were identified through information from other actors by performing a bottom-up driven snowball approach (Atkinson and Flint 2004).

During the interviews, questions focused first on the social context (e.g., lineage/clan affiliation, legitimation) and daily livelihood activities of the interviewees, then on their implication in decision making for natural resource management, their perception of (in)formal rules and their interaction with external actors. Supplementary group discussions facilitated observations of negotiation processes amongst actors. This method was combined with participatory mapping with individuals and groups, for example social and resource maps (Narayanasamy 2009). These tools help to understand the distribution of ethnic groups, clans and lineages in populated areas and to gain an insight into their perception of property of land and natural resources (private and common). Through participatory and systematic observation (e.g., (ir)regular meetings, daily activities, rituals) it was possible to identify new actors relevant for the research and to understand their relationship.

To validate the collected information, the same questions were repeated with different persons in different places and time (data triangulation); close cooperation was carried out with Malagasy colleagues doing research in related domains in the same area (investigator triangulation), and different methods were applied for data collection such as interviews, observation, participatory techniques (methodological triangulation) (Denzin 1970). Data analysis was realised with the computer-supported program Atlas.ti, which facilitated the treatment of the transcribed audio files and the code-based elaboration of theory (Smit 2002).

\section{RESULTS}

TANALANA ACTORS AND DECISION MAKING. Tanalana society consists of three clans (raza)-Tevondrone, Temitongoa/Tetsivalea and Temilahehe-subdivided into several lineages (famosora), each headed by a traditional chief. While clan members refer to a supposedly historical founding ancestor to whom they do not necessarily trace genealogical links, the people of a lineage refer to a common real nameable consanguineous ancestor. The clan and lineage chiefs (mpitan-kazomanga lava and mpitan-kazomanga fohe, respectively) are chosen by criteria of genealogy and age; they are responsible for performing rituals to maintain the balance of the human and the supernatural world. They are a moral, symbolic, honorific or divine authority enforced through their direct relationship to the traditional creator (Zanahary) and the ancestors (raza). The traditional chiefs are advised by other elders (olobe/roandria) who are the main actors responsible for decision making and conflict resolution in Tanalana society. These elders, consisting of several persons of the main lineages, have significant influence on the placement of persons in administrative (chef de fokontany, mayor) and traditional (clan and lineage chiefs) positions (Figure 2). Although gerontocracy and genealogy predetermine the succession of the chief positions, the elders can exclude the suggested candidate if he is assessed as unworthy because of unsocial behaviour or a lack of social recognition. The foundation of a clan or lineage is linked to the establishment of a holy pale (a wooden construct of different pieces, called a hazomanga), the forging of a holy knife (vy lava) and the enthronization of a traditional chief. It is possible for the post of traditional chief to be vacant for years or decades, the elders managing the lineage or clan without a spiritual head. The traditional chiefs are assumed to possess historical knowledge about rules and structures in society because of their age and position, whereas their capacities and abilities are often limited by their age and physical condition. There are exceptional cases of charismatic chief personalities who have the authority to convene meetings and who are consulted in conflict cases but they are always surrounded by other influential elders.

TANALANA RULES AND PACTS. The social cohabitation of the

Tanalana is structured by the lilin-draza (rules of the ancestors), which describe the totality of all rules and codes of conduct in Tanalana society. The lilin-draza were established by the ancestors at an unknown point in time and are transmitted from generation to generation. These rules are in the 'collective knowledge' (Halbwachs 1967) and often cannot be linked to a concrete date or person.

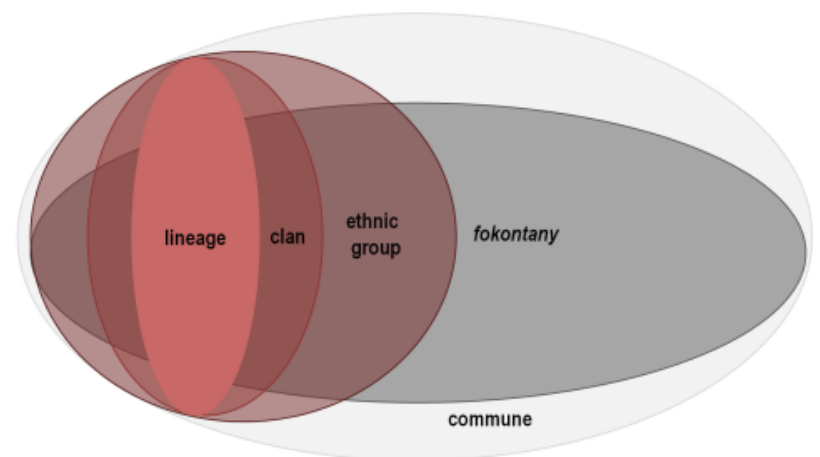

Figure 2. Overlapping levels: (i) administrative levels: fokontany, commune and (ii) social levels: lineage, clan, ethnic group. 
BOX 1. FOKONOLONA. Contrasting the official administrative definition of fokonolona, "all inhabitants of a fokontany" (Decreed N. 2004-299, 3.3.2004) and the original meaning, "members of one clan/lineage", (foko = clan/lineage; olo = people/human being), it is obvious that this term needs a closer inspection (cf. Pollini and Lassoie 2011 for details). What the Tanalana mean by fokonolo (local term for fokonoIona) depends on the context. Both the traditional chief and the chef de fokontany can convene fokonolona ('community') meetings for decision making and conflict resolution. When the Tanalana talk about a meeting convened by the traditional chief or the elders, fokonolo means representatives of a lineage or clan living in one or more fokontany (inner or trans-fokontany fokonolo). When they refer to a fokonolo meeting at the fokontany level which is convened by the chef de fokontany, it describes a group of people composed of several members of all ethnic groups, clans and lineages (but not all inhabitants) who come together to discuss a problem concerning the fokontany territory (fokontany-fokonolo). The administrative nomination fokonolo includes several fokonolo, which can be across fokontany boundaries. It has been observed that both fokonolo meetings vary considerably from one occasion to another in composition and number. But Tanalana people often say that it was a meeting of the fokonolo to underline that "everybody" (of the fokontany inhabitants or clan or lineage members) has participated, to reinforce the collective spirit and the importance of the results. Because the number and the persons are not fixed, the most suitable definition for fokonolo, given by an elder, is: "all people who meet at this moment to take a decision" (local resident, Beheloke I, 2011, quote 4:3). An important point to stress is that the fokonolo meeting is not the arena to make democratic decisions or to openly discuss all the ideas in society. In all meetings observed during the field research, the elders made the decision before or outside the official fokonolo meeting (already shown for other regions in Madagascar by Fauroux in 2003, Blanc-Pamard and Fauroux in 2004). (... ) "[W]hen we have to make an important decision, (...) only the elders meet and after taking the decision, we convene the fokonolo. For this [pre]decision the main lineages of the village meet." (local resident, Ampotake 2013, quote 61:7).

The lilin-draza are oral guidelines for the social interaction of the lineages, clans or the entire ethnic group. They describe duties to be accomplished vis-à-vis the supernatural beings (spirits of ancestors, spirits of nature, traditional creator) and other members in society. The Tanalana believe that the land, animals and natural resources are owned by these supernatural beings and only provided to humans for using. This is why the Tanalana perform rituals of demand and gratitude in different contexts of natural resource use, for example when they work the earth or practice hatsake (slash and burn cultivation). The lilin-draza indicate how and when to practice rituals to honour elders and supernatural beings. "Before you clear the forest, you take a black chicken or a sheep to apologize to the supernatural beings, who are the owners of the forest, so that nothing will happen during the clearing process and we are not blessed by the machete (...)." (local resident, Ampotake 2013, quote 40:45).

The lilin-draza also designate what is private property, e.g., fenced fields, livestock pens and houses. The land is property of the respective clan or lineage. This lineage land is provided to families or individuals. The forest area and the pasture area outside the agricultural fields is common property, of the trans-fokontany boundary fokonolo, and also accessible for other users with or without kinship or direct social relations. These areas are used as pasture, as well as providing a source for the collection of alimentary and medicinal plants, firewood and construction materials; they are also used for hunting and ritual practice.

Taboos (fady called faly in Tanalana dialect), which are a part of the rules of ancestors (iliin-draza), prohibit using certain species of plants and animals or entering or polluting sacred land (tane faly) or sacred forest (ala faly). Places are faly when spirits of nature or ancestors reside there, or if the holy pale (hazomanga) of the traditional chief is planted. These interdictions of conduct have different origins (ancestors, spirits of nature, diviner-healer) and can concern individuals, families, lineages, clans or the entire ethnic group. The place taboos are also binding for outsiders who are not members of the belief system.

The elders and supernatural beings ensure compliance of the lilin-draza (including faly). If a lilin-draza is transgressed, the elders or the supernatural beings can demand that the person concerned perform a purification ritual (hifikifike) with a sacrificial animal-a chicken, goat or in serious cases, zebu cattle. Many interviewees reported that supernatural beings express their discomfort with the manner of using natural resources through dreams and by forcing people to apologize through compensation rituals (for other examples in Madagascar, cf. Bidaud Rakotoarivony and Ratrimoarivony 2006). The Tanalana believe that if the transgressor does not follow the advice of the elders and/ or the supernatural beings, he/ she can be condemned to divine sanction (hakeo), which results in negative consequences like illness, diminution of goods or a general imbalance between humans and the supernatural world. In cases of rule transgression that concern the well-being of the whole group (e.g., pollution of a spiritual place), the social pressure to perform a ritual is higher than in cases of individual taboo transgression (e.g., ignorance of an alimentary taboo); it can even result in social exclusion by the traditional chief.

When defiance of a lilin-draza directly harms another person, family, lineage, clan or the entire ethnic group, the elders discuss the fee that the culprit has to pay in the form of livestock as indemnification. The form and amount of punishment is not fixed but negotiated case by case; sanctions depend on (a) the frequency of transgression, (b) the place of transgression, (c) the amount of affected persons, (d) the social relationship of the transgressor/ culprit and the damaged party, (e) the social status of the transgressor, and (f) his/ her behaviour during the meeting in the past and present. The elders are responsible for weighing the different factors and their effect on the formulation of social and/ or financial sanctions. In our study, we observed that lilin-draza serve as a basis for discussion, yet are interpreted differently depending on the context. "(...) [T]here are people in our village who have transgressed taboos: they made their field near the tombs of ancestors, cut ancestral trees that are places for sacrifices and deforested the area around the funeral sites. So we were forced to make a first meeting with the traditional chief (mpitan-kazo- 
manga) to discuss the situation. So the chief was forced to formulate the sanctions of one goat per person who has transgressed the lilin-draza." (local resident, Marofijery 2013, quote 1:1).

Lilin-draza are frequently transgressed. Interviewees offer a diversity of reasons for these transgressions: (a) a lack of kinship leading to feeling unconcerned, (b) poverty and the lack of alternative income possibilities for natural resource use, (c) a change of beliefs from obeying the hazomanga (holy pale) and spirits of nature to following Christianity. It is also possible that sacred places lose their faly status because the spirit has left the place and the people have stopped practicing rituals. Taboos are only stable when people value the objects and places regularly through sacrifices and prayer. People might not feel concerned by lilin-draza if they do not fear the individual moral or material consequences; the majority nevertheless use these rules as reference for conflict-management processes when interacting with other members of Tanalana society. Except for place taboos, the prohibitions are not valid for outsiders of Tanalana society; for example, while the Tanalana stick to the taboo not to hunt and eat the radiated tortoise (Astrochelys radiata), they indicate the abode of the animal to other consumers and hunters. The handling of this taboo shows the group specificity and permeability of taboos; it also illustrates that taboos in Madagascar do not automatically serve conservation aims (for a discussion of taboos in the context of conservation in Madagascar, see Walsh 2002, Horning 2003a, 2003b, Tengö et al. 2007, Jones et al. 2008, Keller 2009).

Another form of agreement among the Tanalana is the titike (vow or curse). This can be a form of social pact or a sincerity oath, the former action is used as a conflict prevention tool amongst individuals and/ or groups, the latter for identifying culprits. The oath contains maledictions and aims to influence the conscience of the person who has already done and may still do a crime. The Tanalana believe that supernatural beings take responsibility to identify and punish the (potential) culprit. People are connected by a symbolic tie and enter in a common agreement of mutual trust by reducing mistrust. This ritual is performed especially in the context of transhumance as an inner and intra-ethnic moral connection of herders and host communities (littoral and plateau). These pacts are performed by a lineage elder or lineage chief according to demand on the fokontany level; they connect the transhumance guests (Tanalana and Mahafaly groups) with the resident Tanalana population. In 2013 it was additionally performed by the clan chiefs concerning the whole ethnic group Tanalana and their related groups.

A third form of rules are dina (rules/pacts/social convention), which are established on the fokontany or commune level, or in the context of CBM (Supplementary Material). They are formalised in written documentation and legalised on the court level. Bérard (2009) distinguishes 'indigenous dina' (traditional oral rules equivalent to the Tanalanas' lilin-draza), 'customary dina' (formalised rules established during the (post)colonial period) and 'dina GELOSE' (formalised rules established in the context of CBM). It is not possible to determine the exact moment of origin of an 'indigenous dina' in a local society, but researchers agree that the term dina was first used in a wider political context during the regime of King Andrianampoinimerina (Condominas 1961, Bérard 2009). The meaning of the term dina underwent several changes within Madagascar's history, guided by different aims of control or decentralisation of power (Bérard 2009, Andriamalala and Gardner 2010), and hence the term does not mean the same for the per- sons living in the Malagasy highlands as it does for the coastal inhabitants. The Tanalana define dina as the formalised rules (fokontany, commune, CBM) and use the term lilin-draza to describe the orally transmitted rules that are blessed by the ancestors. "For the vazaha [the state, foreigners or development agencies], they have their lilin-draza, which are the dina; in turn the traditional society, like ours, we have our dina, which are the lilin-draza; and every party tries to see which are the most adaptable to their milieu." (local resident, Ampotake 2013, quote 95:3).

COMMUNITY-BASED RESOURCE MANAGEMENT NEAR TSIMANAMPESOTSE NATIONAL PARK. The initial idea of the conservation agencies for the implementation of the CBM was the elaboration of a set of rules (dina GELOSE/ GCF or dina COBA) based on the already existing local rules (Iilin-draza/faly) so as to assure that members of the COBA associations identify with the protection of their own natural resources (GELOSE law 96-025, Article 49). However our finding show that the Tanalana have no lilin-draza, faly or titike that clearly determines an amount for natural resource use. There are some taboos prohibiting the use of certain natural resources and certain resources that are considered private property, but they do not focus on sustainable use or equitable distribution. Furthermore lilin-draza are sometimes lineage or clan specific: for example, the taboo to hunt the bird Turnix nigricollis is not binding for all clans and hence cannot serve as a common basis for CBM.

The operating conservation agencies (WWF, MNP, GIZ and Tany Meva) hence prefer to establish new rules for the CBM but push this procedure through pre-formulated rules and predetermined time schedules. In contrast to the local rhythm and timeline for rule negotiation the new rules are fixed only in about two meetings. Furthermore, promoters of CBM (especially WWF and $\mathrm{GIZ}$ appropriated the concept of taboo concerning the whole ethnic group by naming one of the zones in the transferred area ala faly (sacred forest) (cf. Keller 2009). This zone is equivalent to a core zone in the National Park where natural resource use is strictly forbidden by the national law, but it has no reference to local beliefs: "the sacred forest [in the CBM area] is not taboo in the traditional perception (...) it was an order of the WWF" (local resident, Beheloke haut 2012, quote 35:3). In the absence of regular ritual practice, the local population does not perceive a place as taboo and continue using natural resources.

The new COBA rules, like the locally established rules, are not perceived as fixed entities and are variously interpreted by the local population (see also Andriamalala and Gardner 2010, Rives et al. 2013). There is even a rule violation that is unofficially institutionalized. Two COBAs on the plateau allow their members to practice slash and burn (hatsake) for a small amount of money distributed to the association. Slash and burn is used by the Tanalana for gaining new agricultural fields and bushfires for stimulating fodder plant growth for raising livestock. In the COBA contract, its prohibition follows the (inter-)national conservation paradigm (cf. Scales 2011, 2014, Keller 2008). This contrasts the Iocal perception that land is the guarantor for life and the continuity of mankind (Keller 2008). Disposing enough land for future generations and the multiplication of cattle, who are the highest cultural and economic good, is in the main interest of Tanalana people. Access to ancestral land (tanin-draza) through deforestation is very often not refused by the executive board of the COBA if the person has enough manpower to cultivate the land. Furthermore, 
social cohesion (fihavanana, filongoa in local accent) and kinship relations hinder the application of sanctions (for other examples in Madagascar see Andriamalala and Gardner 2010, Fritz-Vietta et al. 2011).

NEGOTIATION OF RULES FOR THE FODDER PLANT SAMATA. In contrast to the externally promoted forms of natural resource management previously presented, this section explores an example of local rule negotiation processes. For about three decades now there has been ongoing negotiation processes in some fokontany over the use of the fodder plant samata (Euphorbia stenoclada) (Figure 3). Because this natural resource exists mainly outside the buffer zone, it has not yet been a focus for conservation agencies. Nonetheless, this paper argues that exploring the processes of negotiation surrounding this example can help point the way for the future design of CBM.

This key resource serves to feed livestock (goats, sheep and mainly cattle), which is the economic and cultural basis of Tanalana society (Fauroux 1997). This plant is used in the littoral, especially in the dry season, by livestock herders (Tanalana and Mahafaly) living on the coast and those coming from the plateau for transhumance. Unsustainable cutting practices, declining precipitation, the expansion of agricultural fields, and longer grazing periods of cattle herds from the plateau because of the threat of cattle raiders has reduced the total number of samata trees in the littoral (cf. Goetter 2016).

In Tanalana society there are three different given statuses for the property of samata trees: (i) samata trees in the pastoral land (monto) are a common pool resource, which means it is: (a) accessible to anybody who is an owner or herder of livestock, without account of his/ her origin; (b) difficult to exclude somebody from; and (c) not available for other users after the subtraction by

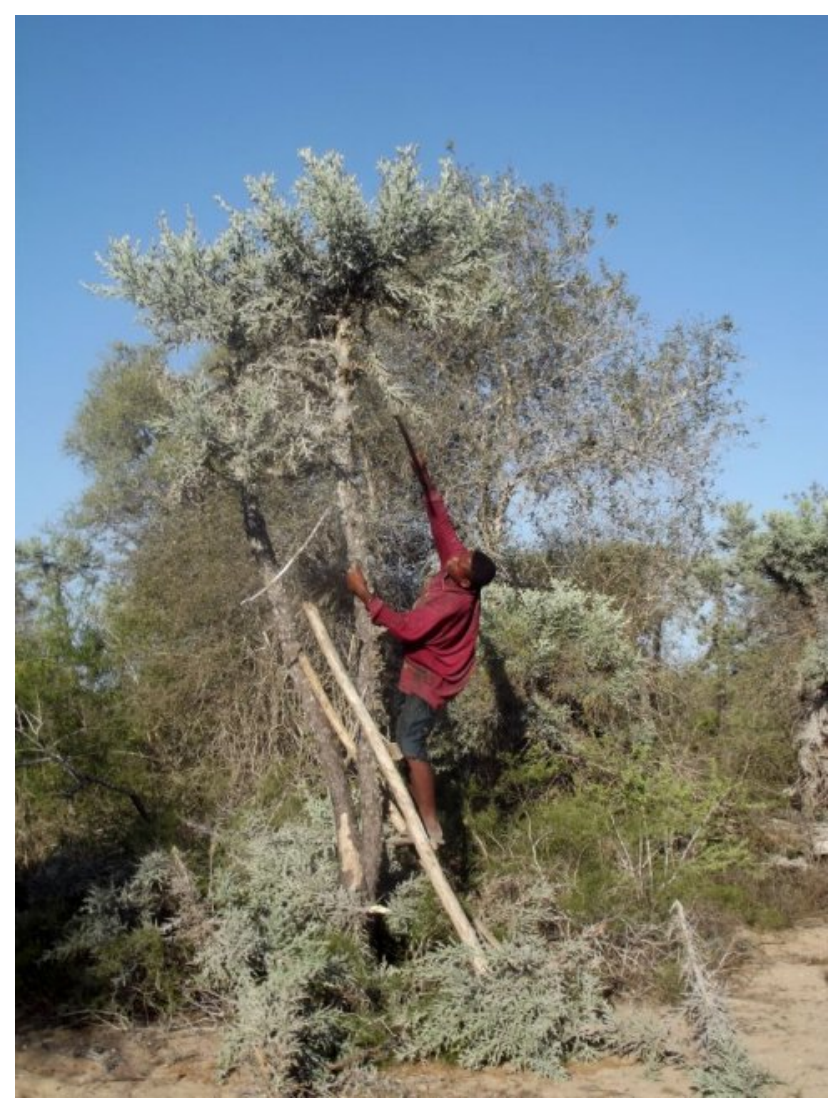

Figure 3. Cattle herder cutting samata tree (Euphorbia stenoclada). somebody (Ostrom 1990). (ii) Samata trees in livestock pens, in private agricultural fields and near houses are accepted and respected as a form of private property (individual, family) according to the lilin-draza. (iii) There is collective property that is excluded from any form of use, like ritual trees and sources of shade in community places like the market. Over the past three decades people have expanded their private property claims on additional samata. The acceptable distance of private use around the livestock pen and the size of enclosures in the pastoral area have been discussed on different levels (fokontany, commune, clan), but no overlapping fokontany solutions have been attained yet. Triggered by increasing conflicts over this fodder plant in a few fokontany, some chef de fokontany addressed the mayor of the commune Beheloke who convened a meeting on the commune level in 2010. Although the mayor and the chefs de fokontany promoted an establishment of a rule, they still have not agreed on a communal dina. Finally the mayor transferred the responsibility back to the chefs de fokontany "because they are closer to the people" (mayor, Beheloke haut, 2011, quote 15:2). The following examples demonstrate that nearly similar constellation of actors can nevertheless cause very different ways of rule negotiations.

In the fokontany Beheloke haut the chef de fokontany consulted the clan chief of the Temahaleotse, who was also the lineage chief of the Tembalaolake, before the communal meeting took place. The clan chief required the liberalisation of samata up to 30 private samata trees around a livestock pen. The rest is declared public for all Tanalana people and their guests. "Concerning the [samata] appropriation, the elder [clan chief] mentioned the ancestors are the owner of the samata plants and the land where the samata grows is also the ancestors' property. Therefore, nobody has the right to appropriate the samata. The samata has to be expropriated." (Local resident, Beheloke haut 2011, quote 13:5).

But the majority of the elders of the main lineages promote the measurement of one hectare of private samata (30 tratra = about 50-60 square meters) around the livestock pen. Nevertheless, many elders are convinced that an effective regulation needs the moral support of the chief, who can reinforce sanctions through his direct relationship to the traditional creator (Zanahare). That is why they try to convince or instrumentalise the traditional chief for their purposes but the clan chief refused to change his initial statement. Additionally, intra- and inter-lineage differences, caused by different amounts in cattle and hence different needs for samata, hinder common agreement. This situation supports my statement that most of the traditional chiefs had more a function as a consultative and morally supportive organ rather than a position as real decision maker.

Another example of rule negotiation took place in the fokontany Marofijery. Some 30 years ago the ex-lineage chief of the Tantsihay (clan Tevondrone) and the surrounding elders supported a mutual idea and established a rule for some aspects of samata use, limiting the private use to one hectare around the livestock pen, only one of which is permitted per cattle owner. Although the content of this rule is perceived as lilin-draza, the negotiation process is remembered and can be described by the majority of the cattle herders. The process is also continuously revisited as persons with large livestock herds often transgress this agreement. This situation shows that lilin-draza are not timeless and unchangeable. Similar to statements from Beheloke haut, the majority of interviewees from Marofijery (elders and young men) underline the importance of including the traditional chief and the ineffecti- 
veness of state institutions. "It is an initiative of the community and permitted by the mpitan-kazomanga (lineage chief of the Tantsihay, part of the clan Tevondrone), so that means it is a lilindraza (rules of the ancestors) (...) [W]hen it is a lilin-draza, it is the responsibility of the traditional chief and not of the chef de fokontany (...) If it was a dina, I'm sure that it would fall through. We take care of our lilin-draza, so we accept the regulation of the private samata because we are determined by the fundamental rules, which are the lilin-draza." (local resident, Marofijery 2013, quote 104:1). "It's right that there are state institutions like the mayor and the chef de fokontany but we have always to ask for permission of our traditional chief because we people of the littoral respect our lilin-draza. (...). The chef de fokontany also has to obey the lilin-draza." (local resident, Marofijery 2013, quote: 114:1).

Although a greater consensus about the regulation of the fodder plant exists in Marofijery than in Beheloke haut, no new rule (dina) could be established or no already existent rule (Iilindraza) could be re-established either. Even if a clear consensus concerning the private status of samata (inside livestock pens, agricultural fields and near houses) and the non-usable collective samata (ritual trees, providers of shade) exist, the sanctions for transgressions are contextually negotiated. While in one case the culprit had to pay two sheep for logging a tree on the market place, another person who cut several trees in another's agricultural field was not punished at all. The first person had already taken another tree from this place without permission and the act damages the whole community as they lose a source of shade. The second person had destroyed more trees but it was on their kin's field. These examples illustrate that even based on the same rule, different settings and conditions cause different sanctions.

Both fokontany cases explored above, Beheloke haut and Marofijery, show that the establishment of rules is a long-term ongoing process. Rules that are already established have to be renegotiated after a certain time and in cases of transgression, are variously interpreted. Moreover, which levels are used for a rule negotiation process, and the order of these, is not fixed and depends on the personal skills of certain people. Finally, actors and their responsibilities on administrative levels (fokontany and commune) and social levels (clan and lineage) overlap and hinder a clear reference framework for the establishment of rules. In the following section I will discuss these problems by analysing different forms of local rules and levels in the context of CBM.

\section{DISCUSSION}

IMPACT FOR COMMUNITY-BASED MANAGEMENT IN THE BUFFER ZONE OF TSIMANAMPESOTSE NATIONAL PARK. One

of the main questions in the CBM context is how to anchor the COBA associations; there is the choice between a geographic level (fokontany) or a social level (clan, lineage), and there is also a choice of what form of agreements and rules (dina, lilin-draza) to use (Blanc-Pamard and Rakoto Ramiarantsoa 2007, Pollini et al. 2014). Most of the COBAs in the research area, like most across Madagascar, are composed of voluntary members from one or more fokontany (see Figure 4, Model I) While the initial idea of the GELOSE-law aims for a transfer of management rights to the whole fokontany-based community (the administrative sense of fokonolo) (see Figure 4, Model II), the passed law text only supports the foundation of an exclusive unit which does not include all resource users (Pollini and Lassoie 2011). Attention is drawn here again to the Tanalanas' perception of fokonolo, which has two dimensions: they have a trans-fokontany identity (lineages and clans), the territorial reference of which is the ancestral tomb, and a fokontany-fokonolo identity, which comprises the inhabitants of a clearly defined administrative territory, the fokontany. There are hence three possibilities for composing the membership of a COBA association: (i) voluntary members of one or more fokontany (Figure 4, Model I), (ii) all resource users in a fokontany concerning the administrative unit (Figure 4, Model II) or (iii) all resource users in all fokontany that concern the clan level (Figure 4, Model III).

Because of the Tanalana's trans-fokontany identity, it is difficult with fokontany-fokonolo decisions to restrict natural resource use outside of the private areas (e.g., fields and livestock pens). All resources in this area, including samata, are perceived as 'common property' (sensu Ostrom 1990) and are accessible to everybody. This perception of property suggests that fokontany boundaries are of little importance for the management of natural resources. Some conservation agencies try to manage the transfokontany border use of natural resources by integrating several fokontany in one COBA association, but these are also only composed of voluntary members and exclude other users of natural resources (see Figure 4, Model Ib) (see also Andriamalala and Gardner 2010).

Despite trans-fokontany identity and resource use, Tanalana make agreements and discuss rules with clear fokontany boundary reference. The small social pact (titike) and the rules for samata use were applied and discussed mainly on the fokontany level. Solutions were additionally searched on the trans-fokontany boundary or clan level, but with less influence on daily behaviour. Ostrom (1990) argues that for successful collective action in natural resource management it is important to define clear boundaries of the people who are using the resources. She specifies this aspect in further publications: "membership [to a user group] may also be marked by symbolic boundaries and involve (...) rituals and beliefs that help solidify individual beliefs about the trustworthiness of others" (Ostrom 2014). In line with this, I argue that it is useful to take a look at these locally initiated agreements, analyse their level of effectiveness and prove their usability for reorganising the community-based natural resource management associations.

In our study, the negotiations observed on the fokontany level concerning the use of samata aim only to control the privatiza-

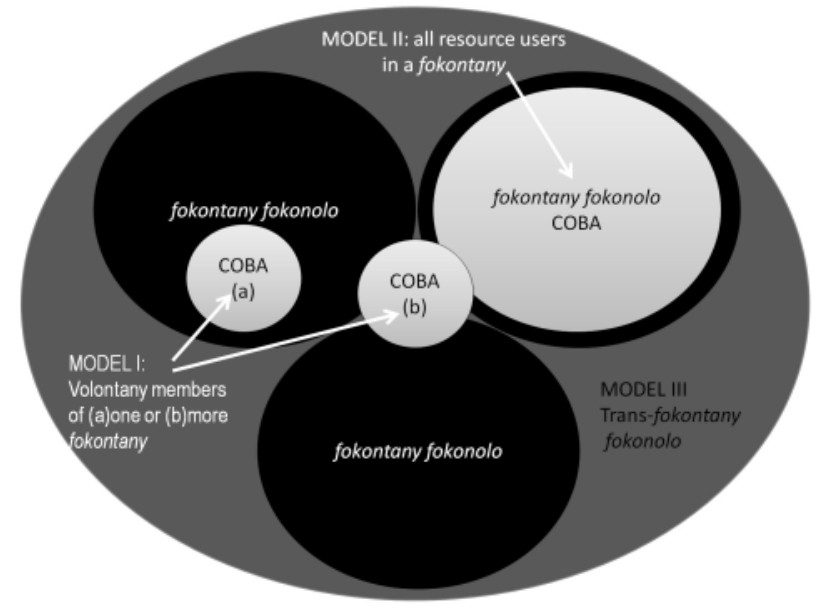

Figure 4. Proposed models for composition of the community-based management associations COBAs (communautés de base). (modified from Pollini et al. 2014) 
tion process inside a fokontany; there is no restriction on genera use of common samata by others as this contradicts the trans-fokontany identity (cf. Goetter 2016). Interviewees mentioned that the reason for integrating the clan chief in the discussion process was not the need to restrict common property access for persons not part of the fokontany-fokonolo, but rather to morally support the decisions made on the lineage level concerning the respective fokontany-fokonolo. Our study supports the conclusion of other researchers that the fokontany-fokonolo level, based on the main lineages, is the reference framework for decision making (cf. Blanc-Pamard and Fauroux 2004, Muttenzer 2010). The same is true for the small titike, which is performed with the respective fokontany-fokonolo members and transhumance guests (Goetter 2016). In spite of the Tanalanas' trans-fokontany identity and resource usage, this study shows that the clan level and its authorities are not as action orientated as the lineage level (fokontany-fokonolo). Consequently, the clan level is not the most effective form to anchor CBM associations. This does not imply a lack of clan identity but only shows the limit of clan authority to influence daily behaviour. The following quote underlines this finding: "This initiative is born in the community of Marofijery. As inhabitants of Marofijery it is our task to find the adequate rules. We do not have to wait for the decision of the clan chief because the clan chief does not have the right to put pressure on our organisation. We have to focus on the essential things in our fokontany. It is the task of our lineage chief who tries to find a consensus for the well-being of our fokontany and a well-established rule." (local resident, Marofijery 2013, quote: 114:2).

The question then arises, could lilin-draza or titike on a fokontany level be a basis for the CBM association's rules? Although researchers have shown that sometimes existing forms of local agreements or institutions can provide more acceptance and respect for CBM structures (Kull 2002, Horning 2003b, Blanc-Pamard and Fauroux 2004), others question their use. For instance, BlancPamard and Fauroux (2004) question the usability of a titike or lilin-draza for CBM among another ethnic group in the southwest of Madagascar, the Sakalava, because of the conservative nature of these rules which reinforce the existing power structures. Additionally, Kull 2002 and Pollini et al. 2014 warn against ignoring the ethnic heterogeneous composition of local societies and hence of COBA associations when forming COBA associations. This critique is valid if we are proposing already existing structures as possible forms for CBM because the fokonolo does not consist of the whole lineage/ clan or all the inhabitants of a fokontany; it is a constantly changing group of persons dominated by the elders of the main Tanalana lineages (for another example in Madagascar, see Goedefroit 2006). The ethnic heterogeneity is partially taken into account since Tanalana authorities discuss and make the pacts and rules, Mahafaly and Vezo groups participate in the ritual procedure and/ or in the financing of the sacrificial animal. They are morally connected through social and kinship relations with the Tanalana, who are then responsible that these related groups respect the agreements. For the duration of their stay, seasonal Mahafaly migrants are temporary members of the Tanalana society and thereby have to follow local rules and pacts. Horning argues that "social contracts" or social pacts are only practiced when there is a special need for social cohesion on selected issues in ethnic heterogenic societies (Horning 2003b). However, this study observes that titike both on the fokontany and clan levels are not only practiced to enforce social cohesion between different ethnic groups (Tanalana, Mahafaly and Vezo groups) but also within Tanalana society.

Further arguments question the application of a titike in the CBM context: cattle and other goods that are integrated in the titike are by consensus classified as private property and are thereby not allowed to be used by others, while forest resources are common property and can be used by everybody. The social pact does not contain concrete formulations of sanctions. If a titike is applied for CBM, the content of the given titike needs to be discussed at the same level of detail as it was for the fodder plant rule negotiation process. While the titike is more of a spontaneous reaction to a menacing security situation, the CBM needs a longterm, more or less stable arrangement. A titike thus cannot serve as a replacement for a dina but it could work as reinforcement.

Regulations for forest resources managed through CBM contracts have mainly failed because of the different economic interests and the trans-fokontany 'use right philosophy' (sensu Esoavelomandroso 1989), as also seen in the case for the fodder plant negotiations. The samata case illustrates the time needed for negotiation processes over use restriction, as well as specifically demonstrating that local actors often reject the application of trans-fokontany rules for trans-fokontany resources. These examples show some of the limits for CBM management arrangements.

\section{CONCLUSION}

Although the CBM approach aims for local population participation, the content, manner and speed for the establishment of rules are highly influenced by conservation agencies. Examples worldwide have shown that locally evolved rules are more binding for local people than externally imposed or initiated arrangements (Baland and Platteau 1996, Ostrom 2000, Horning 2004). Nevertheless, it is important to state that local rules are neither entirely respected, nor are they per se sustainable or effective for biodiversity conservation (Walsh 2002, Horning 2003b, 2004).

If conservationists are interested in supporting collective action for sustainable resource management on local levels, they have to be aware of long periods of rule negotiation (Berkes 2004, Goetter and Neudert 2016). Even when the moment of establishing a rule arrives, it is important to remember that existing rules are constantly being renegotiated. Furthermore, each existing rule is interpreted depending on the context and does not raise the claim of general validity and stability. Agreements that are made in a specific context (e.g., cattle theft) or for a specific resource (e.g., samata) cannot be transferred automatically to other conflicts or other natural resources.

Rules that are established in the context of CBM (dina GELOSE) are subject to the same mechanisms as locally initiated rules (lilin-draza, titike): transgression and adaption to individual needs are an integral part of the system (Rives et al. 2013). It is difficult to find the right form of agreements for CBM and also to identify the right level to anchor the CBM association. Each level is problematic in different ways : (i) A COBA association consisting of voluntary members of one or more fokontany (Model la and b), excludes other resource users (Pollini and Lassoie 2011), (ii) a COBA association consisting of all people in a fokontany (fokontanyfokonolona) (Model II) contradicts the trans-fokontany resource use philosophy (Goetter and Neudert 2016), and (iii) a COBA association on the commune or clan level (Modell III) is not action orientating for the local people in their daily behaviour (Kull 2002, 
Blanc-Pamard and Fauroux 2004). The optimal solution would be to establish a dina on the commune and fokontany level based on a rule of ancestor or taboo that includes at least all Tanalana clans and is reinforced annually by a titike that obliges other ethnic groups to follow the agreement. However, this is only possible for some specific resources and not for the whole set of rules needed for CBM.

\section{REFERENCES}

Andriamalala, G. \& Gardner, C. 2010. L'utilisation du dina comme outil de gouvernance des ressources naturelles: leçons tirés de velondriake, sudouest de Madagascar. Tropical Conservation Science 3 (4): 447-472. Available at <goo.gl/yDnpVZ>

Antona, M., Biénabe, E. M., Salles, J.-M., Péchard, G., Aubert, S. and Ratsimbarison, R. 2004. Rights transfers in Madagascar biodiversity policies: achievements and significance. Environment and Development Economics 9, 6: 825-847. (doi:10.1017/S1355770X04001640)

Astuti, R. 1995. 'The Vezo are not a kind of people': identity, difference, and 'ethnicity' among a fishing people of western Madagascar. American Ethnologist 22, 3: 464-482. (doi:10.1525/ae.1995.22.3.02a00010)

Atkinson, R. and Flint, J. 2004. Snowball sampling. In: Encyclopedia of Social Science Research Methods. M. S. Lewis-Beck, A. Bryman, T. F. Liao (eds.), pp 1423-1432. SAGE Publications, Thousand Oaks.

Baland, J.-M. and Platteau, J.-P. 1996. Halting degradation of natural resources: is there a role for rural communities? FAO and Oxford University Press.

Bérard, M. H. 2009. Légitimité des Normes Environnementales et Complexité du Droit: I'Exemple de I'Utilisation des Dina dans la Gestion Locale de la Forêt à Madagascar (1996-2006). Unpubl. Ph.D. thesis, Université de Laval, Québec. Available at <www.theses.ulaval.ca/2009/26361/26361_1.pdf>

Bérard, M.-H. 2011. Légitimités et normes environnementales dans la gestion locale de la forêt à Madagascar. Canadian Journal of Law \& Society 26, 1 : 89-111. (doi:10.3138/cjls.26.1.089)

Berkes, F. 2004. Rethinking community-based conservation. Conservation Biology 18, 3: 621-630. (doi:10.1111/j.1523-1739.2004.00077.x)

Bertrand, A., Aubert, S., Montagne, P., Lohanivo A. C. \& Razafintsalama, M. H. 2014. Madagascar, politique forestière: Bilan 1990-2013 et propositions. Madagascar Conservation \& Development 9, 1: 20-30. (doi:10.4314/mcd.v9i1.4)

Bidaud Rakotoarivony, C. and Ratrimoarivony, M. 2006. Terre ancestrale ou parc national? Entre la légitimité sociale et légalité à Madagascar. Vertigo - La Revue Électronique en Sciences de l'Environnement 7, 2: 1-10

Blanc-Pamard, C. \& Fauroux, E. 2004. L'illusion participative. Exemples ouestmalgaches. Autrepart 31, 3: 3-19. (doi:10.3917/autr.031.0003)

Blanc-Pamard, C. \& Rakoto Ramiarantsoa, H. 2007. Normes environnementales, transferts de gestion et recompositions territoriales en pays Betsileo (Madagascar). Natures Sciences Sociétés 15, 3: 253-268. (doi:10.1051/nss:2007055)

Commune Beheloke, WWF, ANGAP \& GTZ 2005. Monographie de la commune Beheloke. Toliara.

Condominas, G. 1960. Fokon'olona et Collectivitées Rurales en Imerina. BergerLevrault, Paris. Available at <http://horizon.documentation.ird.fr/exldoc/pleins_textes/divers11-03/22732.pdf>

Cullmann, G. 2015. Community forest management as virtualism in northeastern Madagascar. Human Ecology 43, 1: 29-41. (doi:10.1007/s10745-015-9725-5)

Denzin, N. K. (ed.) 1970. Sociological Methods: A Sourcebook. Aldine Atherton, chicago.

Eggert, K. 1981. Who are the Mahafaly? Cultural and social mis-identifications in southwestern Madagascar. Omaly Sy Anio (Hier et Aujourd'hui), Revue d'Études Historiques Antananarivo 13-14: 149-176.

Esoavelomandroso, M. 1989. Territoires et troupeaux des Temitongoa. In: Histoire et Organisation de l'Espace à Madagascar. J. Fremigacci (ed.), pp 47-56. Karthala, Paris.
Fauroux, E. 1997. Les Éleveurs de l'Ouest Malgache face aux Difficultés Économiques du Dernier Quart du XXe siècle. Paper presented at the conference 'Atelier Ménages et Crises' Marseille 24-26 March 1997. Available at <http://ow.ly/TOiPn>

Fauroux, E. 2003. Structures micro-locales du pouvoir et gouvernance dans les villages de I'Ouest malgache. In: La Gouvernance Locale à Madagascar: Représentation, Modélisation, Participation. M. Langlois, P. Méral, L. Raharinirina Rabaovololona, B. S Ralalaoherivony (eds.), pp 2-18. Cahiers du C3EDM

Freudenberger, K. 2010 Paradise Lost? Lessons from 25 Years of USAID Environment Programs in Madagascar. Final Report U.S. Agency for International Development (USAID). International Research Group, Washington DC. Available at <https://goo.gl/ZOZeci>

Fritz-Vietta, N., Röttger, C. and Stoll-Kleemann, S. 2009. Community-based management in two biosphere reserves in Madagascar-distinctions and similarities: What can be learned from different approaches? Madagascar Conservation \& Development 4, 2: 86-97. (doi:10.4314/mcd.v4i2.48648)

Fritz-Vietta, N. V. M., Ferguson, H. B., Stoll-Kleemann, S. and Ganzhorn, J. U. 2011. Conservation in a biodiversity hotspot: Insights from cultural community perspectives in Madagascar. In: Biodiversity Hotspots. F. E. Zachos and J. C. Habel (eds.), pp 209-233. Springer-Verlag, Berlin/Heidelberg.

Gardner, C. J., Ferguson, B., Rebara, F. and Ratsifandrihamanana, A. N. 2008. Integrating traditional values and management regimes into Madagascar's expanded protected area system: the case of Ankodida. In: Protected Landscapes and Cultural and Spiritual Values. J.-M. Mallarach (ed.), pp 92-103. Kasparek Verlag, Heidelberg.

Goedefroit, G. 2006. La restitution du droit à la parole. Études Rurales 178, 2 39-64.

Goetter, J. F. 2016. The cattle raiders leave us no choice: New transhumance in the Mahafaly Plateau region in Madagascar. Madagascar Conservation \& Development 11, 1: 12-22. (doi:10.4314/mcd.v11i1.3)

Goetter, J. F. and Neudert, R. 2016. New rules are not rules: Privatization of pastoral commons and local attempts at curtailment in southwest Madagascar. International Journal of the Commons 10, 2: 617-641. (doi:10.18352/ijc.743)

Halbwachs, M. 1967 Das kollektive Gedächtnis. Enke, Stuttgart.

Hanson, P. W. 2012. Towards a more transformative participation in the conservation of Madagascar's natural resources. Geoforum 43, 6: 1182-1193. (doi:10.1016/j.geoforum.2012.03.005)

Horning, N. R. 2000. Conference Paper. Explaining compliance with rules governing forest common pool-resource and conservation: dynamics in Bara Country. Southwestern Madagascar. Presented at Constituting the Commons: Crafting Sustainable Commons in the New Millennium, Eighth Conference of the International Association for the Study of Common Property, Bloomington, Indiana. 31.5- 4.6.2000. Available at <goo.gl/sSXfd7>

Horning, N. R. 2003a. The cost of ignoring rules: forest conservation and rural livelihood outcomes in Madagascar. Forests, Trees and Livelihoods 15, 2 : 149-166. (doi:10.1080/14728028.2005.9752517)

Horning, N. R. 2003b. How rules affect conservation outcomes. In: The Natural History of Madagascar. S. M. Goodman and J. P. Benstead (eds.), pp 146-153. The University of Chicago Press, Chicago.

Horning, N. R. 2004. The Limits of Rules: When Rules Promote Forest Conservation and When They Do Not - Insights from Bara Country, Madagascar. Unpubl. Ph.D. thesis, Cornell University, Cornwell. Available at <goo.gl/AlQbF7>

Jones, J. P. G., Andriamarovololona, M. M. and Hockley, N. 2008. The importance of taboos and social norms to conservation in Madagascar. Conservation Biology 22, 4: 976-986. (doi:10.1111/j.1523-1739.2008.00970.x)

Keller, E. 2008. The banana plant and the moon: Conservation and the Malagasy ethos of life in Masoala, Madagascar. American Ethnologist 35, 4: 650-664. (doi:10.1111/j.1548-1425.2008.00103.x)

Keller, E. 2009. The danger of misunderstanding 'culture'. Madagascar Conservation \& Development 4, 2: 82-85. (doi:10.4314/mcd.v4i2.48647)

Kull, C. A. 2002. Empowering pyromaniacs in Madagascar: ideology and legitimacy in community-based natural resource management. Development and Change 33, 1: 57-78. (doi:10.1111/1467-7660.00240) 
Larson, P. M. 1996. Desperately seeking 'the Merina' (central Madagascar): reading ethnonyms and their semantic fields in African identities history. Journal of Southern African Studies 22, 4: 541-560. (doi:10.1080/03057079608708511)

Marcus, R. R. and Kull, C. 1999. Setting the stage: the politics of Madagascar's Environmental efforts. African Studies Quarterly 3, 2: 1-8.

Mercier, J.-R. 2006. The preparation of the National Environmental Action Plan (NEAP): Was it a false start? Madagascar Conservation \& Development 1, 1: 50-54. (doi:10.4314/mcd.v111.44122)

Muttenzer, F. 2006. Conference Paper. Coutume Ancestrale et Droit Coutumier: Problème de Connaissance et de Reconnaissance des Droits Fonciers. Colloque International 'Les Frontières de la Question Foncière. Montpellier. Available at <goo.gl/FQyaSF>

Muttenzer, F. 2010. Déforestation et Droit Coutumier à Madagascar: Les Perceptions des Acteurs de la Gestion Communautaire des Forêts. Karthala, Paris.

Myers, N., Mittermeier, R. A., Mittermeier, C. G., da Fonseca, G. A. B. and Kent, 2000. Biodiversity hotspots for conservation priorities. Nature 403, 6772 : 853-858. (doi:10.1038/35002501)

Narayanasamy, N. 2009. Participatory Rural Appraisal: Principles, Methods and Application. SAGE Publications, New Delhi.

Ostrom, E. 1990. Governing the Commons: The Evolution of Institutions for Collective Action. Cambridge University Press. Cambridge, UK.

Ostrom, E. 2000. Collective action and the evolution of social norms. Journal of Economic Perspectives 14, 3: 137-158. (doi:10.1257/jep.14.3.137)

Ostrom, E. 2014. Collective action and evolution of social norms. Journal of Natural Resources Policy Research 6, 4: 235-252. (doi:10.1080/19390459.2014.935173)

Pollini, J. 2011. The difficult reconciliation of conservation and development objectives: The case of the Malagasy Environmental Action Plan. Human Organization 70, 1: 74-87. (doi:10.17730/humo.70.1.6879m4w585133302)

Pollini, J. and Lassoie, J. P. 2011. Trapping farmer communities within global environmental regimes: the case of the GELOSE legislation in Madagascar. Society \& Natural Resources 24, 8: 814-830. (doi:10.1080/08941921003782218)

Pollini, J., Hockley, N., Muttenzer, F. D. and Ramamonjisoa, B. S. 2014. The transfer of natural resource management rights to local communities. In: Conservation and Environmental Management in Madagascar. I. R. Scales (ed.), pp 172-192. Routledge, London and New York.

Poyer, L. and Kelly, R. L. 2000. Mystification of the Mikea: constructions of foraging identity in southwest Madagascar. Journal of Anthropological Research 56, 2: 163-185. (doi:10.1086/jar.56.2.3631361)

Raik, D. 2007. Forest management in Madagascar: An historical overview. Madagascar Conservation \& Development 2, 1: 5-10. (doi:10.4314/mcd.v2i1.44123)

Rives, F., Carrière, S. M., Montagne, P., Aubert, S. and Sibelet, N. 2013. Forest Management Devolution: Gap between technicians' design and villagers' practices in Madagascar. Environmental Management 52, 4: 877-893. (doi:10.1007/s00267-013-0138-1)

Scales, I. R. 2011. Lost in translation: conflicting views of deforestation, land use and identity in western Madagascar. The Geographical Journal 178, 1: 67-79. (doi:10.1111/j.1475-4959.2011.00432.x)

Scales, I. R. 2014. The future of conservation and development in Madagascar: time for a new paradigm? Madagascar Conservation \& Development 9, 1: 5-12. (doi:10.4314/mcd.v9i1.2)

Smit, B. 2002. Atlas.ti for qualitative data analysis. Perspectives in Education 20, 3 : 65-76.

SuLaMa 2011. Recherche Participative pour Appuyer la Gestion Durable des Terres du Plateau Mahafaly dans le Sud-ouest de Madagascar: Diagnostic Participatif de la Gestion des Ressources Naturelles sur le Plateau Mahafaly Commune Rurale Beheloke. Rapport final SuLaMa (ed.). SuLaMa, Tuléar. Available at <http://www.sulama.de/files/rapport_marp_2011_mid.pdf>

Tengö, M., Johansson, K., Rakotondrasoa, F., Lundberg, J., Andriamaherilala, J.-A., Rakotoarisoa, J.-A. and Elmqvist T. 2007. Taboos and forest governance: Informal protection of hot spot dry forest in southern Madagascar. AMBIO 36, 8: 683-691. (doi:10.1579/0044-7447(2007)36[683:TAFGIP]2.0.CO;2)
Waeber, P. O., Wilmé, L., Ramamonjisoa, B., Garcia, C., Rakotomalala, D., et al. 2015. Dry forests in Madagascar: neglected and under pressure. International Forestry Review 17, S2: 127-148. (doi:10.1505/146554815815834822)

Waeber, P. O.,Wilmé, L., Mercier, J. R., Camara, C. and Lowry II, P. P. 2016. How effective have thirty years of internationally driven conservation and development efforts been in Madagascar? PLOS ONE 11, 8: e0161115. (doi:10.1371/journal.pone.0161115)

Walsh, A. 2002. Responsibility, taboos and 'The freedom to do otherwise' in Ankarana, northern Madagascar. Journal of the Royal Anthropological Institute 8, 3: 451-468. (doi:10.1111/1467-9655.00117)

Yin, R. K. 2003. Case Study Research, Design and Methods. SAGE Publications Inc., Thousand Oaks.

\section{SUPPLEMENTARY MATERIAL.}

Available online only.

Table S1. Different types of rules in the context of natural resource management. 
Thielsen, K. 2016. Which form of agreement works for community-based management? Case study from southwestern Madagascar. Madagascar Conservation \& Development 11, 2: 66-76.

http://dx.doi.org.104314/mcd.v11i1.5 Supplementary Material

Table S1. Different types of rules in the context of natural resource management.

\begin{tabular}{|c|c|c|c|c|c|}
\hline Rule & Area concerned & $\begin{array}{l}\text { Persons/institutions } \\
\text { responsible for } \\
\text { establishment }\end{array}$ & $\begin{array}{l}\text { Persons } \\
\text { concerned }\end{array}$ & $\begin{array}{l}\text { Persons/ beings } \\
\text { responsible for } \\
\text { sanctions }\end{array}$ & $\begin{array}{l}\text { Importance for } \\
\text { the use of } \\
\text { resources }\end{array}$ \\
\hline \multicolumn{6}{|c|}{ Customary rules and pacts (oral / non formalised) } \\
\hline $\begin{array}{l}\text { Lilin-draza (Rules } \\
\text { of ancestors) }\end{array}$ & $\begin{array}{l}\text { Everywhere (inside } \\
\text { and outside the } \\
\text { protected areas) }\end{array}$ & $\begin{array}{l}\text { Ancestors, Diviner- } \\
\text { healer, Supernatural } \\
\text { beings }\end{array}$ & $\begin{array}{l}\text { Clan, Lineage, } \\
\text { Ethnic group }\end{array}$ & $\begin{array}{l}\text { Elders of the main } \\
\text { lineages } \\
\text { Supernatural } \\
\text { beings }\end{array}$ & $\begin{array}{l}\text { Determines form } \\
\text { of property social } \\
\text { and spiritual } \\
\text { interaction }\end{array}$ \\
\hline $\begin{array}{l}\text { Faly (Taboo which } \\
\text { are part of the lilin- } \\
\text { draza) }\end{array}$ & $\begin{array}{l}\text { Certain places and } \\
\text { certain resources }\end{array}$ & $\begin{array}{l}\text { Ancestors, Diviner- } \\
\text { healer, Supernatural } \\
\text { beings }\end{array}$ & $\begin{array}{l}\text { Individual, Clan, } \\
\text { Lineage, Ethnic } \\
\text { group or } \\
\text { everybody } \\
\text { (Malagasy and } \\
\text { foreigner) }\end{array}$ & $\begin{array}{l}\text { Elders of the main } \\
\text { lineages, } \\
\text { Supernatural } \\
\text { beings }\end{array}$ & $\begin{array}{l}\text { Prohibits the use } \\
\text { of certain species } \\
\text { (animals and } \\
\text { plants), on certain } \\
\text { days and in } \\
\text { certain places }\end{array}$ \\
\hline \multirow[t]{2}{*}{$\begin{array}{l}\text { Titike (Social pact } \\
\text { or sincerity oath) }\end{array}$} & a) fokontany & $\begin{array}{l}\text { a) lineage elder or } \\
\text { chief }\end{array}$ & $\begin{array}{l}\text { a) inhabitants of a } \\
\text { fokontany and } \\
\text { guests }\end{array}$ & \multirow{2}{*}{$\begin{array}{l}\text { Elders of the main } \\
\text { lineages, } \\
\text { Supernatural } \\
\text { beings }\end{array}$} & \multirow{2}{*}{$\begin{array}{l}\text { Concerns } \\
\text { removable objects } \\
\text { and difficult to } \\
\text { apply in the CBM } \\
\text { context }\end{array}$} \\
\hline & b) regional & b) clan elder or chief & $\begin{array}{l}\text { b) all Tanalana } \\
\text { and related ethnic } \\
\text { groups }\end{array}$ & & \\
\hline \multicolumn{6}{|c|}{ Dina = rule $/$ convention (written $/$ formalised) } \\
\hline $\begin{array}{l}\text { Dina fokontany } \\
\text { (fokontany rule) }\end{array}$ & $\begin{array}{l}\text { Area of the } \\
\text { fokontany (villages } \\
\text { and related } \\
\text { hamlets) }\end{array}$ & $\begin{array}{l}\text { Administrative } \\
\text { fokonolo } \\
\text { (representatives of } \\
\text { the inhabitants of the } \\
\text { fokontany) }\end{array}$ & $\begin{array}{l}\text { All the inhabitants } \\
\text { of the fokontany }\end{array}$ & $\begin{array}{l}\text { Chef de fokontany } \\
\text { and Administrative } \\
\text { fokonolo }\end{array}$ & $\begin{array}{l}\text { Does not exist in } \\
\text { study region }\end{array}$ \\
\hline $\begin{array}{l}\text { Dina GELOSE for } \\
\text { the community- } \\
\text { based } \\
\text { management }\end{array}$ & $\begin{array}{l}\text { Transferred area in } \\
\text { the buffer zone of } \\
\text { the } \\
\text { Tsimanampesotse } \\
\text { National Park }\end{array}$ & $\begin{array}{l}\text { Members of the } \\
\text { COBA }\end{array}$ & $\begin{array}{l}\text { Members of the } \\
\text { COBA. }\end{array}$ & $\begin{array}{l}\text { Executive bureau } \\
\text { of the COBA } \\
\text { association }\end{array}$ & $\begin{array}{l}\text { Determines the } \\
\text { period and amount } \\
\text { of logging, hunting } \\
\text { and collecting } \\
\text { natural resources } \\
\text { and the } \\
\text { reforestation } \\
\text { duties }\end{array}$ \\
\hline \multicolumn{6}{|c|}{ State law (formalised) } \\
\hline $\begin{array}{l}\text { Forest Law no. } \\
97-017,8.8 .1997\end{array}$ & $\begin{array}{l}\text { Outside the } \\
\text { protected areas }\end{array}$ & $\begin{array}{l}\text { Ministry of } \\
\text { Environment, } \\
\text { Ecology, the Sea and } \\
\text { Forest }\end{array}$ & $\begin{array}{l}\text { Everybody } \\
\text { (Malagasy and } \\
\text { foreigner) }\end{array}$ & $\begin{array}{l}\text { Forest agent, } \\
\text { Forest \&Water } \\
\text { Directorate, } \\
\text { Regional }\end{array}$ & $\begin{array}{l}\text { Determines the } \\
\text { period and amount } \\
\text { of logging in the } \\
\text { state forest }\end{array}$ \\
\hline $\begin{array}{l}\text { Code for the } \\
\text { management of } \\
\text { protected areas } \\
\text { (COAP law no. } \\
2001-005 \text {, } \\
11.2 .2003 \text { ) }\end{array}$ & $\begin{array}{l}\text { All protected areas } \\
\text { in Madagascar } \\
\text { including } \\
\text { Tsimanampesotse } \\
\text { National Park }\end{array}$ & $\begin{array}{l}\text { Ministry of } \\
\text { Environment, } \\
\text { Ecology, Sea and } \\
\text { Forest }\end{array}$ & $\begin{array}{l}\text { Everybody } \\
\text { (Malagasy and } \\
\text { foreigner) }\end{array}$ & $\begin{array}{l}\text { Madagascar } \\
\text { National Parks } \\
\text { (MNP), Forest } \\
\text { agent, Forest \& } \\
\text { Water Directorate, } \\
\text { Regional }\end{array}$ & $\begin{array}{l}\text { Determines the } \\
\text { period and amount } \\
\text { of logging, hunting } \\
\text { and collecting of } \\
\text { some natural } \\
\text { resources }\end{array}$ \\
\hline
\end{tabular}

